\title{
PENGELOLAAN KONFLIK DAN PEMETAAN BLOK PEMANFAATAN BERSAMA MASYARAKAT DI KHDTK LOA HAUR, KALIMANTAN TIMUR
}

\author{
Elfa Rifadi ${ }^{1}$, Muhammad Sumaryono ${ }^{2}$, Rujehan $^{2}$ \\ ${ }^{1}$ Program Magister Ilmu Kehutanan, Fakultas Kehutanan \\ Universitas Mulawarman. \\ ${ }^{2}$ Fakultas Kehutanan, Universitas Mulawarman, Jl Ki Hajar Dewantara Kampus Gunung \\ Kelua, Samarinda, Kalimantan Timur, Indonesia 75119, Indonesia. \\ E-Mail: ilhamm1911@gmail.com
}

\begin{abstract}
ABSTRAK
Pengelolaan Konflik Dan Pemetaan Blok Pemanfaatan Bersama Masyarakat Di KHDTK Loa Haur, Kalimantan Timur. Sebagai bagian kawasan yang terletak di KPA Taman Hutan Raya Bukit Soeharto, KHDTK Hutan Pendidikan dan Pelatihan (HPP) Loa Haur memiliki potensi dan ancaman yang sama dalam hal penebangan liar, penambangan liar, kebakaran dan perambahan. Perambahan diantaranya telah menimbulkan konflik kepentingan dalam pemanfaatan ruang di KHDTK Loa haur. Penelitian ini bertujuan untuk melakukan studi pengelolaan konflik dan menyediakan strategi pengelolaan bersama masyarakat dalam KHDTK Loa HPP Loa Haur. Penelitian dilakukan dalam 5 (lima) tahapan, yaitu pengumpulan peta dasar dan citra SPOT 6 interpretasi citra, pendataan perambahan, identifikasi kebijakan pengelolaan, pengelolaan konflik dan kelembagaan KTH. Pengelolaan konflik diantara dilakukan melalui grup diskusi yang terarah yang dilengkapi dengan analisis terhadap kekuatan, kelemahan, peluang dan tantangan yang tersedia. Dihipotesakan bahwa konflik dapat diubah menjadi satu kesepakatan yang dapat dipetakan dalam Sistem Informasi Geografis (SIG) dalam bentuk peta blok pemanfaatan ruang bersama masyarakat. Penelitian ini memberi hasil bahwa jumlah lahan yang dimanfaatkan sebanyak 20 lokasi lahan, dengan luas 43,58 ha dan rata-rata 2,18 ha. Jumlah lahan yang teridentifkasi pernah dimanfaatkan dan lalu ditelantarkan dan tanpa identitas adalah lebih banyak. Diindikasikan lahan-lahan tersebut disimpan (land bank) untuk motif ekonomi dari isu kandungan batubara di KHDTK HPP Loa Haur. Komoditi tanaman yang diusahakan adalah dari jenis karet dan buah-buahan (durian, lai dan rambutan). Jenis potensial untuk dapat dikembangkan dalam pemanfaatan ruang bersama masyarakat adalah Gaharu, Kopi dan Kakao. Jenis kelembagaan yang diperlukan untuk mendukung program Kemitraan Kehutanan adalah Kelompok Tani Hutan. Disamping itu, Forum Komunikasi KTH perlu diinisiasikan untuk membuka ruang komunikasi antara petani dengan pengelola sehingga menstimulasi kemajuan program ke depan.
\end{abstract}

Kata kunci : Tahura Bukit Soeharto, KHDTK HPP Loa Haur, Resolusi Konflik, Pemetaan Partisipatif, KTH.

\begin{abstract}
Conflict management and Mapping of Land Use with Community on Loa Haur Forest Area with Special Purpose - Education and Training Forest, East Borneo. KHDTK HPP Loa Haur has a similar potential and threat from illegal logging, illegal mining, forest fires, and encroachment. The encroachment has caused a conflict of interest in the land-use utility in KHDTK Loa haur. This study aims to manage conflict and provide community co-management strategies in KHDTK Loa HPP Loa Haur. The research has 5 (five) stages, namely: map and SPOT 6 imagery interpretation data collection, land use inventory, management policy identification, conflict resolution and CBFM institutional analysis. Conflict management is conducted through focus group discussions that are complemented by SWOT Analysis (strengths, weaknesses, opportunities and threats. It is hypothesized that the conflict can be transformed into an agreement that can be mapped in the Geographic Information System (GIS) in the form of a community spatial block bloc map. This study gives results that the amount of land used as much as 20 land sites. There
\end{abstract}


is a significant number of lands that is not utilized again by community and without identity. There is an indication these lands are stored (land bank) for economy motive, especially coal potential in KHDTK HPP Loa Haur. Rubber and fruits (durian, lao, and rambutan) plants are preferred commodity, while some potential plants are gaharu, coffee, and cocoa. Forest farmer group (Kelompok Tani Hutan/KTH) is a form of institution to support the CBFM program. Besides that there is a need to establish a communication forum of CBFM for increasing communication between farmer and forest manager.

Key words : KHDTK HPP Loa Haur, Conflict Resolution, Participatory Mapping, CBFM.

\section{PENDAHULUAN}

Pemerintah Indonesia menetapkan Kawasan Hutan dengan Tujuan Khusus (KHDTK) untuk kepentingan umum bidang penelitian dan pengembangan; pendidikan dan latihan serta religi dan budaya (UU 41, 1999). Penetapannya dilakukan melalui Keputusan Menteri dengan tidak mengubah fungsi kawasannya sebagai Hutan Konservasi, Hutan Lindung ataupun Hutan Produksi. Salah satu KHDTK dari 7 KHDTK di Provinsi Kalimantan Timur KHDTK Hutan Pendidikan dan Pelatihan (HPP) Loa Haur dengan luas 4.310 hektar (Kepmen 8815, 2002). Kawasan KHDTK HPP Loa Haur termasuk dalam fungsi konservasi yang merupakan bagian dari Kawasan Pelestarian Alam (KPA) Taman Hutan Raya (Tahura) Bukit Soeharto. Tahura Bukit Soeharto memiliki total luas 67.766 ha (Anonim, 2009).

KHDTK HPP Loa Haur terletak di dalam fungsi Kawasan Pelestarian Alam (KPA) Taman Hutan Raya (Tahura) Bukit Soeharto yang mempunyai fungsi pokok perlindungan sistem penyangga kehidupan, pengawetan keaneka-ragaman jenis tumbuhan dan satwa, serta pemanfaatan secara lestari sumber daya alam hayati dan ekosistemnya (KLHK, 2017; DIPSDH, 2017). Sebesar $78,71 \%$ penggunaan kawasan di Tahura Bukit Soeharto sesuai dengan fungsinya, sementara itu, 21,29\% pengunaan kawasan yang tidak sesuai dengan fungsi kawasan (Suryadi dkk, 2017). Sebagai bagian dari kawasan Tahura Bukit Soeharto, KHDTK Hutan Pendidikan dan Pelatihan (HPP) Loa Haur memiliki masalah penggunaan kawasan dan gangguan yang sama. Diantaranya penebangan liar, penambangan liar, kebakaran, perambahan serta okupasi lahan dalam bentuk penambangan batubara liar, perkebunan serta konflik antara pemerintah pusat dan daerah atas kewenangan sumber daya alam (Boer dkk., 2007; Hendar, 2014; Moeliono dan Purwanto, 2008). Perambahan lahan, yang selanjutnya disebut dengan pemanfaatan ruang kawasan oleh Masyarakat di dalam KHDTK HPP Loa Haur dominan dalam bentuk bentuk pembukaan lahan untuk perladangan. Penelitian ini menearik hipotesa bahwa perambahan tersebut dipicu karena peningkatan kebutuhan lahan akibat pertambahan jumlah penduduk di desa sekitar KHDTK (Anonim, 2009). Aktifitas perambahan tersebut berpotensi konflik dalam pemanfaatan ruang antara pengelola KHDTK dan masyarakat yang merambah.

Di sisi lain, teknologi penginderaan jauh saat ini telah berkembang dengan pesat, baik dalam penggunaan perangkat lunak (software), perangkat keras (hardware) maupun resolusi data satelitnya. Salah satu keunggulan teknologi ini adalah dapat menampilkan berbagai data dan informasi tentang keadaan dan fenomena permukaan bumi dalam waktu yang cepat dan akurat (Purwadhi dkk., 1999; Vaiphasa dkk., 2005). Selain itu, teori dan praktek Pengelolaan Hutan Bersama Masyarakat (PHBM) juga telah mengalami perkembangan yang baik dan telah banyak mempengaruhi perubahan persepsi dan pemahaman dalam pengelolaan kawasan hutan dari pendekatan keamanan ke pendekatan 
kesejahteraan. Prinsip-prinsip yang dikembang-kan dalam PHMB diantaranya akomodatif, partisipatif, keterbukaan, kebersamaan, akun-tabel, kesepahaman hak dan tanggung jawab, kejelasan kelembagaan dan berorientasi pada peningkatan usaha produktif menuju masyarakat mandiri dan hutan lestari (Anonim, 2007).

Berdasarkan uraian masalah dan teori diatas, penelitian ini memiliki tiga tujuan, yaitu : 1) Mengetahui jumlah pemanfaatan ruang oleh masyarakat di dalam KHDTK HPP Loa Haur dan ruang terbuka lainnya sebagai database dalam pengelolaan konflik. 2) Mengidentifikasi kekuatan, kelemahan, ancaman dan tantangan dalam pengelolaan. 3) Menyediakan strategi pengelolaan kawasan bersama masyarakat yang bersinergi dengan tujuan penetapan KHDTK HPP Loa Haur sebagai laboratorium pendidikan dan pelatihan kehutanan.

\section{METODA PENELITIAN}

2.1. Tempat dan Waktu Penelitian ini dilaksanakan di KHDTK HPP Loa Haur selama 6 bulan, yaitu Mei - Nopember 2017.

\subsection{Bahan dan Alat}

Bahan utama yang digunakan adalah : Peta KHDTK Hutan Diklat Loa Haur. Peta Batas Administrasi Kabupaten Kutai Kartanegara.
Peta Kawasan Tahura Bukit Soeharto

Citra SPOT 6 tahun 2012

Peta Topografi KHDTK HPP Loa Haur.

Peta Penutupan Lahan KHDTK HPP Loa Haur.

Peta Hidrologi KHDTK HPP Loa Haur.

Peta Sistem Lahan Kalimantan Timur.

Peta Rencana Pengelolaan KHDTK HPP Loa Haur.

Peralatan Survey Lapangan :

GPS DNR Garmin CSX 60/76

Kompas

Clinometer

Tally Sheet

Kamera Digital.

\subsection{Prosedur Penelitian}

Penelitian dilakukan dalam 3 (tiga) tahapan utama, yaitu 1). pengumpulan peta dasar dan citra SPOT 6, 2) interpretasi citra, 3). Pendataan dan resolusi konflik dalam pemanfaatan ruang aktif oleh masyarakat. Tiga tahapan ini meliputi juga analisis dan identifikasi terhadap ruang terbuka. Luaran dari tahapan-tahapan kegiatana tersebut adalah peta arahan blok pemanfaatan dan strategi pengelolaan. Tahapan ini dilakukan berdasarkan kerangka operasional penelitian seperti disajikan pada Gambar 1. 


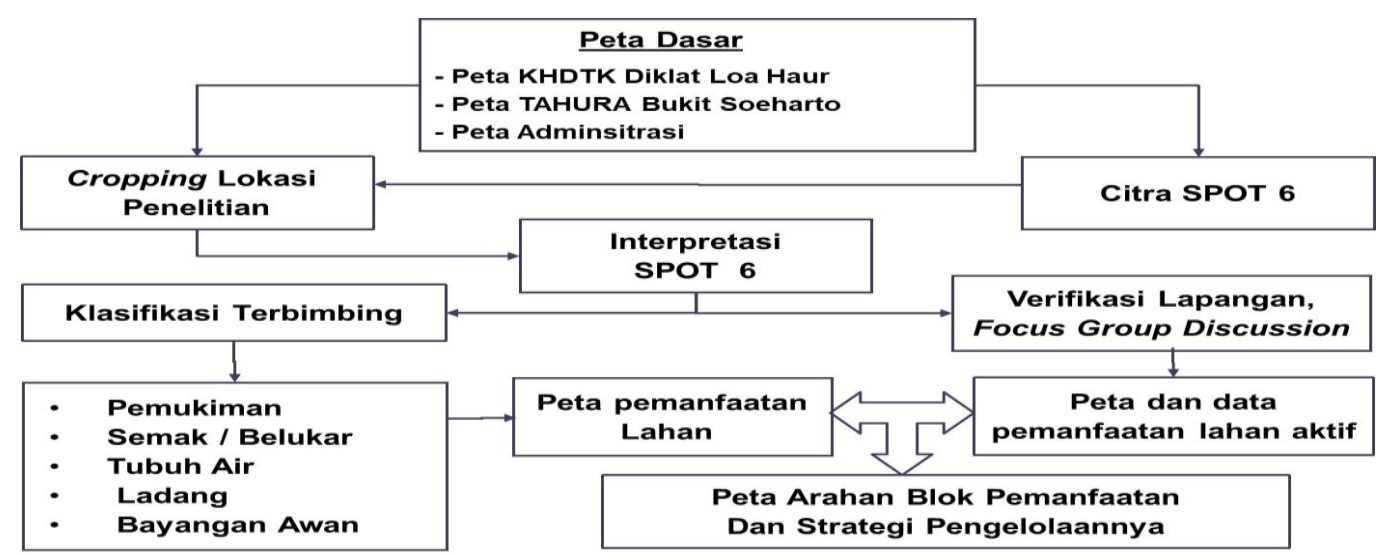

Gambar 1. Kerangka Operasional Penelitian

Detail tentang tahapan tersebut adalah sebagai berikut

\subsubsection{Pengumpulan Data Peta Dasar dan Citra}

Pengumpulan data yang meliputi peta analog dan digital diperoleh dari Balai Pemantapan Kawasan Hutan Wilayah IV Samarinda dan Balai Diklat Kehutanan Samarinda, sedangkan data tabular diperoleh dari Badan Lingkungan Hidup Provinsi Kalimantan Timur dalam angka. Citra yang digunakan adalah Citra SPOT 6 Liputan Tahun 2012 yang diperoleh dari Lembaga Penerbangan dan Antariksa Nasional (LAPAN)

\subsubsection{Interpretasi Citra}

Interpretasi atau pengolahan data citra adalah kegiatan perkiraan suatu objek berdasarkan bentuk tone, tekstur, lokasi, asosiasi yang tampak pada citra. Interpretasi citra satelit SPOT 6 melalui koreksi geometri, penajaman citra, cropping lokasi penelitian, klasifikasi NDVI (Normalized Difference Vegetation Index) dan pengklasifikasian tutupan lahan. Klasifikasi NDVI dilakukan dengan mengukur intensitas kehijauan dari pantulan gelombang cahaya yang berasal dari klorofil dedaunan di permukaan bumi (Sudiana dan Diasmara, 2008). Indeks kehijauan vegetasi pada citra berupa skala antara -1 (yang biasanya air) hingga +1 (vegetasi lebat) yang diperoleh dengan membandingkan reflektansi vegetasi yang diterima pada panjang gelombang merah (R) dan infra merah dekat (NIR). Persamaan yang digunakan untuk menghitung NDVI adalah :

$$
\begin{aligned}
& \text { NDVI }=(\mathrm{NIR}-\mathrm{R}) /(\mathrm{NIR}+\mathrm{R}), \\
& \text { dimana : } \\
& \begin{array}{l}
\text { NIR } \\
\text { piksel } \\
\mathrm{R}
\end{array} \quad \text { Radiasi infra merah dekat dari }
\end{aligned}
$$

Reklasifikasi (reclassify) berfungsi untuk mengklasifikasi atau mengklasifikasi kembali suatu data spasial (atribut) yang baru dengan menggunakan kriteria tertentu (Prahasta, 2002). Reklasifikasi juga berfungsi untuk memperbaiki tampilan visual dengan pemberian nama dan warna yang berbeda untuk setiap kelas tutupan sehingga terlihat perbedaan antar kelas tutupan lahan yang di analisis. 
2.3.3. Pendataan dan resolusi konflik dalam pemanfaatan ruang oleh masyarakat

Pendataan pemanfaatan ruang pemanfaatan dalam kawasan KHDTK HPP Loa Haur dilakukan dengan menggunakan media kuisioner dengan format isian tentang identitas, luas lahan, komoditi garapan, kesediaan menjadi anggota Kelompok Tani Hutan (KTH). Responden adalah orangorang dalam komunitas masyarakat di sekitar KHDTK yang memanfaatkan ruang secara aktif dalam kawasan KHDTK sebagai lahan garapan. Penetapan responden menggunakan teknik sampling snowball (bola salju), yaitu diperoleh melalui penggalian informasi dari satu responden sebelumnya ke responden berikutnya secara berantai, hingga diyakini informasi berhenti di responden terakhir (Nurdiani, 2014). Pendataan diperkaya cek lapangan (groundcheck) keberadaan lahan garapan. Selain itu, juga dilakukan wawancara terbuka yang bertujuan untuk mengidentifikasi persepsi dan pemahaman responden tentang fungsi dan keberadan KHDTK, faktor pemicu pemanfaatan lahan dalam KHDTK, pemahaman tentang pengelolaan hutan bersama masyarakat dan informasi-informasi penting lainnya.

Resolusi konflik dilakukan dalam forum diskusi terfokus (Focus Group Discussion/FGD). FGD diikuti oleh masyarakat penggarap lahan dan pengelola serta peneliti sebagai fasilitator. FGD bertujuan untuk menghasilkan resolusi terhadap konflik pemanfaatan lahan melalui perubahan pola pikir berkonflik karena perbedaan nilai, pandangan, aktivitas, status, dan kelangkaan sumberdaya alam (Marina dan Dharmawan, 2011). FGD mengarahkan perubahan pola pikir untuk memperoleh kesepakatan pengelolaan bersama yang partisipatif. Dalam FGD dirumuskan peran, tanggung jawab dan kelembagaan dalam PHBM. Pengukuran lapangan menggunakan teknik tracking dan pengambilan titik-titik koordinat pada setiap sudut lokasi yang diukur dengan alat bantu GPS (Global Positioning System), Kompas, Klinometer dan Meteran. Masyarakat bertindak sebagai pengukur dan penunjuk batas, sedangkan peneliti bersama pengelola menjadi pendamping yang mengarahkan masyarakat dalam teknik pengukuran.

\subsubsection{Analisis Strategi Pengembangan Dengan Menggunakan Matrik SWOT}

Untuk membuat analisis strategi pengembangannya, terlebih dahulu diidentifikasi faktor internal dan eksternal dari KHDTK HPP Loa haur. Analisis SWOT menghasilkan 4 (empat) kemungkinan alternatif strategi (Rangkuty, 2000) disajikan pada matriks perumusan strategi analisis SWOT pada Gambar 2 dan Tabel 1. 


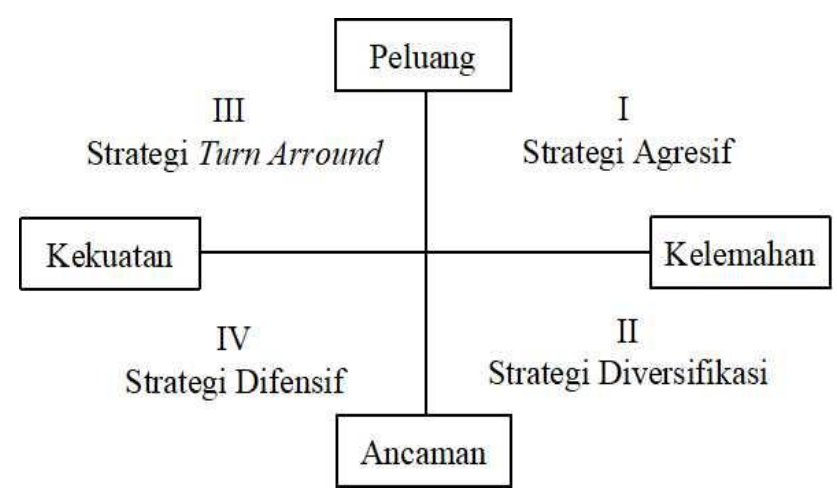

Gambar 2. Matrik Grand Strtategi (Grand Matrix Strategy)

Keterangan Gambar :

Kuadran I : Strategi ini dibuat berdasarkan jalan pikiran pengelola KHDTK, yaitu dengan memanfaatkan seluruh kekuatan untuk merebut dan memanfaatkan peluang sebesarbesarnya. 2.

Kuadran II : Ini adalah strategi dalam menggunakan kekuatan yang dimiliki pengelola KHDTK untuk mengatasi ancaman.

Kuadran III : Strategi ini diterapkan berdasarkan pemanfaatan peluang yang ada dengan cara meminimalkan kelemahan yang ada.

Kuadran IV : Strategi ini didasarkan pada kegiatan yang bersifat defensif dan berusaha meminimalkan kelemahan yang ada serta menghindari ancaman.

Tabel 1. Matriks Strategi Analisis SWOT (Matrix Strategy SWOT Analysis)

\begin{tabular}{|l|l|l|}
\hline $\begin{array}{l}\text { Faktor Internal } \\
\text { Eksternal faktor }\end{array}$ & $\begin{array}{l}\text { Strengths (S) Tentukan faktor } \\
\text { kekuatan internal }\end{array}$ & $\begin{array}{l}\text { Weaknesses (W) Tentukan } \\
\text { faktor kelemahan internal }\end{array}$ \\
\hline $\begin{array}{l}\text { Opportunities (O) } \\
\text { Tentukan faktor peluang }\end{array}$ & $\begin{array}{l}\text { Starategi SO Ciptakan } \\
\text { strategi yang menggunakan } \\
\text { kekuatan } \\
\text { memanfaatkan peluang }\end{array}$ & $\begin{array}{l}\text { Strategi WO Ciptakan } \\
\text { strategi yang meminimalkan } \\
\text { kelemahan untuk } \\
\text { memanfaatkan peluang }\end{array}$ \\
\hline $\begin{array}{l}\text { Threats (T) Tentukan faktor } \\
\text { ancaman Ekternal }\end{array}$ & $\begin{array}{l}\text { Strategi ST Ciptakan strategi } \\
\text { yang menggunakan kekuatan } \\
\text { untuk mengatasi ancaman }\end{array}$ & $\begin{array}{l}\text { Strategi WT Ciptakan } \\
\text { strategi yang meminimalkan } \\
\text { kelamahan dan menghindari } \\
\text { ancaman }\end{array}$ \\
\hline
\end{tabular}

Sumber : Diadopsi dari Rangkuty 2000 


\section{HASIL PENELITIAN DAN PEMBAHASAN}

\subsection{Kondisi Umum KHDTK HPP Loa Haur}

Secara geografis KHDTK HPP Loa Haur terletak antara $0^{\circ} 40^{\prime} 00^{\prime}$ - $0^{\circ} 46^{\prime} 00^{\prime}$ ' LS dan $116^{\circ} 6^{\prime} 00^{\prime \prime}$ - $117^{\circ} 01^{\prime} 00$ BT. Secara administrasi pemerintahan, terletak dalam wilayah Kecamatan Loa Janan, Kabupaten Kutai Kartanegara, yang meliputi 3 (tiga) wilayah Pemerintahan Desa, yaitu Loa Duri Ulu, Loa Duri Ilir dan Bakungan.

Berdasarkan data curah hujan Tahun 2015 (Anonim, 2015), rata-rata curah hujan bulanan sebesar $183 \mathrm{~mm}$ dan rata-rata hari hujan per bulan sebesar 14 hari. Curah hujan tertinggi terjadi pada bulan Januari, yaitu sebesar $273 \mathrm{~mm}$ dengan 22 hari hujan, sedangkan curah hujan terendah terjadi pada bulan September, yaitu sebanyak $92 \mathrm{~mm}$ dengan 8 hari hujan (Anonim, 2015 ${ }^{\mathrm{a}}$ ). Menurut Sumaryono dkk. (2017), KHDTK HPP Loa Haur termasuk dalam tipe iklim A menurut Schmidt dan Ferguson dengan nilai Q < $14,3 \%$ yang merupakan daerah sangat basah (hutan hujan tropis).

Sebagai bagian dari kawasan Tahura Bukit Soeharto, KHDTK HPP Loa Haur termasuk dalam kompleks bentukan fisiografi Lembah Kutai dan Jalur lipatan bukit (Kutai Valley and Ridge Fold Belts) yang secara umum bergelombang dengan ketinggian tempat antara 50-1500 meter (Anonim, 2006 dalam Sumaryono dkk, 2009). Mengacu pada Atlas East Kalimantan Transmigration Area Development Project/TAD, maka kondisi fisiografi dan topografi kawasan penelitian merupakan perbukitan yang memanjang dengan arah sejajar dengan jalur pantai dari Balikpapan ke Samboja, atau dari Balikpapan menuju timur laut kemudian di kawasan Samboja menuju ke utara.

Posisi Tahura Bukit Soeharto ini terletak pada posisi yang tertinggi dan puncaknya adalah pada titik sekitar km 56 jalan poros Samarinda-Balikpapan dengan ketinggian 145 meter dpl. Pada posisi demikian, Tahura Bukit Soeharto memberi pengaruh iklim kota Balikpapan dari kawasan laut sampai puncak tertinggi dengan iklim lautnya, sementara dari puncak tertinggi ke kota Samarinda dengan iklim daratnya. Bila penutupan vegetasi di Tahura Bukit Soeharto terbuka atau rusak maka kota Balikpapan yang mempunyai iklim lebih basah akan menjadi kering, sementara kota Samarinda yang kering menjadi lebih basah. Begitu sebaliknya bila tutupan vegetasi kawasan Tahura terjaga dengan vegetasi yang baik, maka iklim Balikpapan akan tetap basah, sementara Samarinda tetap kering (Sumaryono dkk, 2009).

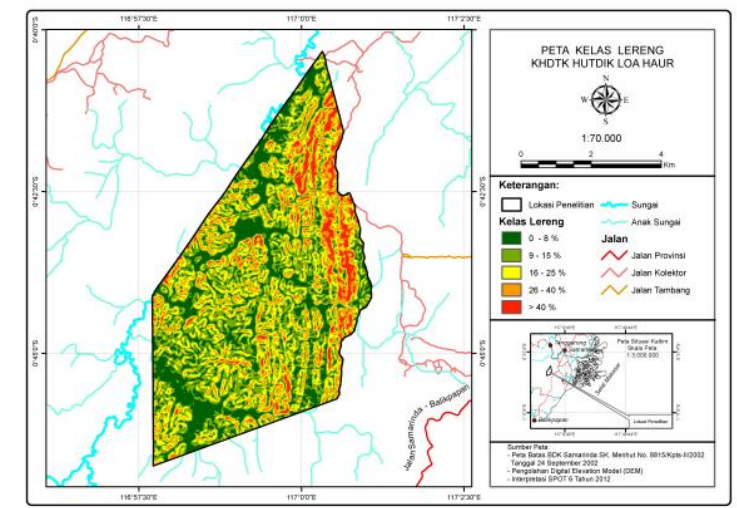

Gambar 3. Peta Kelas Lereng KHDTK Loa Haur

Sumber : data sekunder tahun 2017 
Berdasarkan hasil analisis data DEM dapat diketahui bahwa KHDTK HPP Loa Haur dominan datar hingga landai (0-15\%) yang terdapat di bagian Timur dan Selatan. Seperti disajikan pada Gambar 3 dan Tabel
2, hanya sebesar $1,37 \%$ kawasan dalam kelas kelerengan sangat curam (40\%), secara keseluruhan, semua kelas lereng tersebar sangat acak.

Tabel 2. Luas Kelas Lereng KHDTK Hutan Diklat (HPP) Loa Haur

\begin{tabular}{cccc}
\hline No & Kelas Lereng & Luas (Ha) & Persen (\%) \\
\hline 1 & $0-8 \%$ & $1.425,14$ & 33,07 \\
2 & $8-15 \%$ & $2.153,36$ & 49,96 \\
3 & $15-25 \%$ & 497,72 & 11,55 \\
4 & $25-40 \%$ & 174,70 & 4,05 \\
5 & $>40 \%$ & 59,08 & 1,37 \\
\hline & Jumlah & $\mathbf{4 . 3 1 0}$ & $\mathbf{1 0 0} \%$ \\
\hline
\end{tabular}

Sumber: Hasil Analisis dan Perhitungan Luas KelasLereng Tahun 2017 Dengan Menggunakan Data DEM Tahun 2002.

Berdasarkan peta Geologi Bersistem Indonesia Kalimantan skala 1 : 250.000, formasi geologi di KHDTK HPP Loa Haur terdiri dari Batuan Sedimen Miosen Atas (Tumbul dan Sumaryono, 2017). Seluruh kawasan KHDTK Hutan HPP Loa Haur termasuk dalam Daerah Aliran Sungan (DAS) Loa Haur. DAS ini berbatasan dengan 4 DAS lainnya, yaitu DAS Bakungan, DAS Dondang, DAS Seluang dan DAS Payang. Sumaryono dkk, (2009) mengemukakan bahwa jaringan sungai (drainage network) di KHDTK HPP Loa Haur bercirikan pola percabangan pohon (dendritic pattern). Karena pengaruh faktor topografi dan kapasitas penampung yang terbatas, walaupun termasuk dalam tipe iklim A yang sangat basah dan curah hujan yang tinggi, potensi air di KHDTK HPP Loa Haur terbilang kecil karena limpasan air sungai yang relatif cepat.

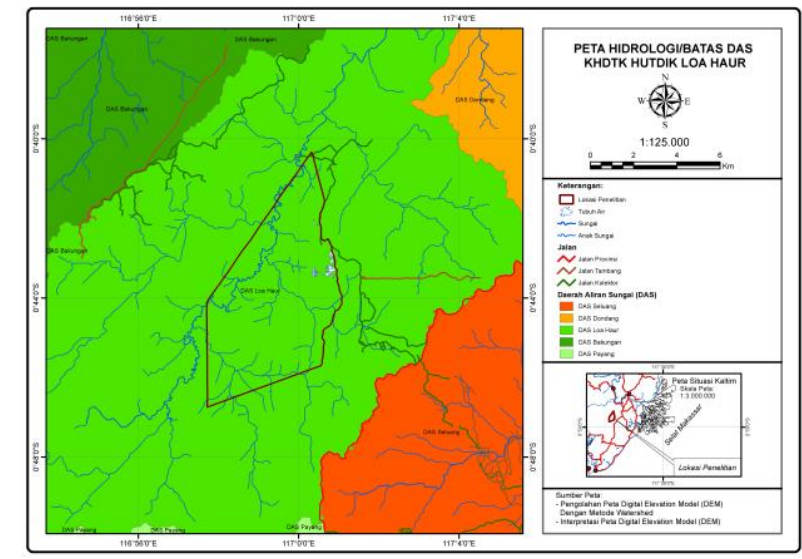

Gambar 4. Peta Hidrologi dan Batas Daerah Aliran Sungai Sumber : data sekunder tahun 2017 
Persentase luas tutupan hutan dengan kerapatan vegetasi tinggi di KHDTK HPP Loa Haur hanya sebesar 25,89\%. Dominansi tutupan lahan adalah tutupan hutan dengan kerapatan vegetasi rendah, yaitu 41,95\% atau dengan sebesar 1.808,46 ha. Sisanya adalah berupa Semak/ Belukar, lahan terbuka atau ladang serta tubuh air, berturut sebesar 28,16\%; 2,95\% dan $1,05 \%$.

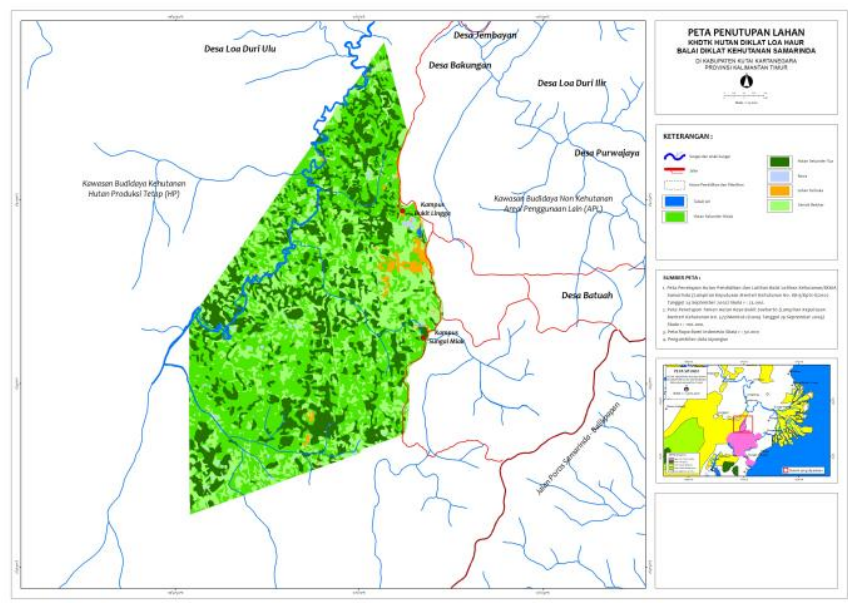

Gambar 5. Peta Tutupan Lahan KHDTK HPP Loa Haur Sumber : pengolahan data tahun 2017

\subsection{Sejarah KHDTK HPP Loa Haur}

Kronologi, sejarah dan legalitas hingga penetapan kawasan hutan Loa Haur sebagai KHDTK HPP Loa Haur adalah sebagai berikut :

Tahun 1979, Balai Diklat Kehutanan Samarinda memperoleh kawasan hutan diklat sesuai dengan Surat Keputusan Direktur Jenderal Kehutanan Nomor: 100/Kpts/DJ/1979 Tanggal 10 Juli 1979 seluas 12.500 hektar yang terletak di Sungai Jembayan-Sungai Loa Haur.

Tahun 1996, Kepala Kantor Wilayah (Kanwil) Departemen Kehutanan Provinsi Kalimantan Timur membentuk Tim Pemantapan Desain Taman Hutan Raya Bukit Soeharto dengan Surat Keputusan Nomor : 912/Kpts/Kwl/KSDA-I/1996 jo Nomor 087/ Kwl/KSDA-I/1996. Hasil dari Tim tersebut diantaranya mengalokasikan Hutan Diklat BLK/SKMA seluas 3.918 hektar.
Tahun 1997, Hutan Diklat BLK/SKMA dialih fungsikan menjadi Hutan Tanaman Industri (HTI) Pulp PT. ITCI berdasarkan Surat Keputusan Menteri Kehutanan Nomor:378/Menhut-IV/1997 Tanggal 03 April 1997,

Tahun 1998, Kepala Kanwil Kehutanan Provinsi Kalimantan Timur menerbitkan Surat Dukungan Penetapan Lokasi Hutan Diklat BLK/SKMA Nomor: 912/Kw1/PTGH-2/1998, tanggal 16 Desember 1998 ditujukan kepada Menteri Kehutanan dan Perkebunan seluas 3.918 hektar di Bukit Soeharto. Lima belas hari berikutnya diperoleh Lembar Disposisi Menteri Kehutanan dan Perkebunan tanggal 31 Desember 1998, perihal Dukungan Penetapan Lokasi Hutan Diklat BLK/SKMA Samarinda seluas 3.918 hektar di Bukit Soeharto.

Tahun 1999, Surat Sekretaris Jenderal Departemen Kehutanan dan Pekebunan kepada Kepala Badan Planologi Nomor : 
1045/II-DIK/UM/1999, 7anggal 22 April 1999, perihal Pengukuhan Hutan Diklat BLK/SKMA Samarinda di Bukit Soeharto.

Tahun 2000, Tata Batas Defenitif Hutan

Diklat BLK/SKMA Samarinda di Bukit

Soeharto dan penetapan panjang batas hutan 30.169,62 meter dan luas 4.310 hektar.

Tahun 2002, Penetapan Hutan Pendidikan dan Pelatihan BLK/SKMA sebagai Kawasan Hutan Dengan Tujuan Khusus (KHDTK) Hutan Pendidikan dan Pelatian (HPP) Loa Haur melalui Surat Keputusan Menteri Kehutanan Nomor: SK. 8815/Kpts-II/2002 tanggal 24 September 2002 seluas 4.310 di Tahura Bukit Soeharto.

3.3. Isu Pemicu Konflik dan Kebijakan Pengelolaan KHDTK HPP Loa Haur

Tiga isu besar yang diidentifikasi sebagai pemicu konflik lahan di KHDTK HPP Loa Haur adalah :

Masyarakat Desa Loa Duri Ilir, Loa Duri Ulu dan Bakungan membuka lahan KHDTK untuk berladang.

Masyarakat Desa Loa Duri Ilir, Loa Duri Ulu dan Bakungan menuntut hak milik untuk lahan yang dibuka. Persepsi terbangun adalah ketidak-berpihakan negara kepada masyarakat terkait keberadaan KHDTK HPP Loa Haur, dimana masyarakat hanya diperbolehkan mengelola lahan.

Isu batubara adalah paling banyak diperbincangkan dalam komunitas masyarakat terkait pembukaan lahan di KHDTK HPP Loa Haur. Informasi atau isu kandungan dan potensi batubara yang tinggi di KHDTK memicu aktifitas pembukaan lahan bertambah. Dalam beberapa kasus, aktiftas pembukaan lahan dialibikan untuk ladang, yang kemudian diklaim dan ditelantarkan, dengan harapan mendapat-kan ganti rugi jika dan jika suatu saat lahan yang diklaim mendapatkan ijin konsesi tambang atau ditambang secara illegal oleh pemodal liar.

Beberapa kebijakan yang melatarbelakangi perencanaan dalam pengelolaan KHDTK HPP Loa Haur antara lain :

Pedoman Kemitraan Kehutanan di KHDTK Kawasan Konservasi/ Pelestarian Alam. Peraturan Menteri Lingkungan Hidup dan Kehutanan No:P.83/MENLHK/SETJEN/

KUM.1/10/2016 Tentang Perhutanan Sosial. Pada poin ketujuh telah mengisyaratkan: Pengelola hutan wajib melaksanakan pemberdayaan masyarakat setempat melalui kemitraan kehutanan (Pasal 40 ayat 1) dan (Pasal 40 ayat 2 ).

Mengacu Permen LHK RI Nomor : P.83/2016, pengelola KHDTK HPP Loa Haur menyediakan 9 petak untuk pengembangan Kemitraan Kehutanan, kode nomor petak 29 dengan jumlah 179,07 , rata-rata 20 ha per petak. Selain itu terdapat demplot Agroforestry dengan luas 4 ha.

\subsection{Sebaran Lokasi dan Bentuk}

Pemanfaatan Ruang Aktif

Karena luas cakupan pemanfaatan ruang yang sangat luas dan adanya keterbatasan waktu penelitian, ruang lingkup untuk identifikasi petani dan sebaran lokasi ruang yang dimanfaatkan dalam penelitian ini dibatasi pada bagian utara KHDTK. Peta sebaran disajikan pada Gambar 6. 


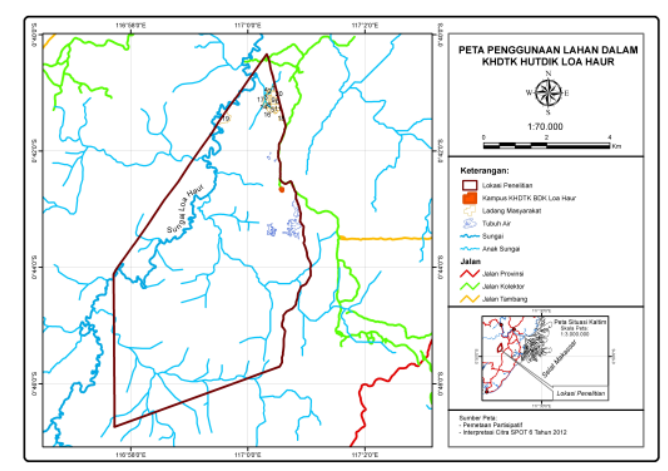

Gambar 6. Peta Pemanfaatan Ruang oleh Masyarakat Sumber : Pengolahan Data tahun 2017

Berdasarkan hasil pelaksanaan verifikasi lapangan terhadap areal pemanfaatan ruang oleh masyarakat, dapat teridentifikasi sebanyak 20 (dua puluh) orang masyarakat yang secara aktif melakukan pemanfaatan ruang di KHDTK HPP Loa Haur, sebagaimana disajikan pada tabel 2 di bawah :

Tabel 3. Identitas, titik ikat (koordinat) dan luas pemanfaatan lahan serta komoditi masyarakat di KHDTK HPP Loa Haur

\begin{tabular}{|c|c|c|c|c|c|}
\hline \multirow{2}{*}{ No } & \multirow{2}{*}{ Nama Penggarap } & \multicolumn{2}{|c|}{ Koordinat UTM } & \multirow{2}{*}{ Luas (ha) } & \multirow{2}{*}{ Komoditi } \\
\hline & & X-UTM & Y-UTM & & \\
\hline 1 & Jamhari & 500781,9769 & 9924638,857 & 2,53 & Karet \\
\hline 2 & Imaniah & 500764,0908 & 9924527,103 & 1,55 & Rambutan \\
\hline 3 & Abu Bakar & 500613,6371 & 9924336,717 & 1,49 & Karet \\
\hline \multicolumn{6}{|c|}{ dst ... } \\
\hline 19 & Safrat & 499271,3787 & 9923674,656 & 8,41 & Padi, Karet \\
\hline 20 & Nafiah & 500846,3625 & 9924401,006 & 3,50 & Rambutan \\
\hline \multicolumn{4}{|c|}{ Jumlah } & \multicolumn{2}{|c|}{43,58} \\
\hline \multicolumn{4}{|c|}{ Rata-rata } & \multicolumn{2}{|c|}{2,18} \\
\hline
\end{tabular}

Sumber : Pengolahan data tahun 2017

Dari tabel 5 tersebut dapat dijelaskan bahwa pemanfaatan ruang oleh masyarakat terdata sejumlah 20 orang petani dengan jumlah luasan lahan dimanfaatkan sebesar 43,58 ha atau $1,02 \%$ dari luas keseluruhan areal KHDTK. Rentang luas lahan garapan adalah $1,01-8,41$ ha dan luas lahan garapan rata-rata 2,18 ha. Jumlah petani dengan luas lahan garapan \pm 2 ha terdiri dari 6 orang dan luas lahan garapan \pm 1 ha sebanyak 11 orang.

\subsection{Strategi Pengelolaan Blok}

Pemanfaatan

Dalam upaya pengelolaan Kawasan Hutan Diklat Loa Haur, seluruh potensi pengelolaan perlu dimanfaatkan, termasuk pemanfaatan ruang terbuka sebagai blok pemanfaatan untuk dikelola dan diberdayakan dalam rangka mencapai visi, misi dan tujuan serta program/kegiatan yang telah ditetapkan. Potensi internal dan eksternal tersebut dapat dilihat dari faktor internal dan faktor eksternal yang mempengaruhi pengelolaan. 


\section{Faktor Internal (Internal Factors) \\ Kekuatan (Strength)}

KHDTK Hutan Diklat Loa Haur telah ditetapkan menjadi Kawasan Hutan Dengan Tujuan Khusus untuk Diklat.

Adanya regulasi dari Pemerintah terkait perhutanan sosial .

Curah hujan yang tinggi.

Tersedianya tenaga Penyuluh Kehutanan dan kegiatan rutin penyuluhan maupun sosialisasi di kawasan.

Memiliki potensi jumlah masyarakat yang cukup untuk membentuk kelompok tani.

\section{Kelemahan (Weaknesses)}

Letak dan assesibilitas kawasan hutan yang kurang mendukung untuk pengelolaan yang optimal.

Potensi limpasan sungai yang tinggi.

Sejarah alih fungsi penetapan kawasan.

Budaya dan kebiasaan pembukaan lahan dengan cara bakar.

Pengalaman dalam pemecahan konflik belum memadai.

\section{Faktor Eksternal (External Factors) Peluang (Opportunity)}

Komitmen pemerintah yang kuat dalam perhutanan sosial.

Persentase luas kawasan bervegetasi jarang dan semak belukar relatif luas

Rencana pengembangan pemberdayaan masyarakat terdapat pada rencana pengelolaan kawasan.

Adanya komitmen para penentu kebijakan di tingkat nasional dan provinsi yang sangat tinggi pada pelestarian sumber daya alam dan lingkungan.

Terdapat penyelenggaraan diklat yang berbasis masyarakat

\section{Ancaman (Threath)}

Isu kandungan batubara di kawasan.

Letak/assesibilitas kawasan sangat dekat dan dikelilingi oleh kegiatan pertambangan.
Meningkatnya jumlah penduduk sekitar kawasan hutan.

Masih rendahnya tingkat pendidikan masyarakat di sekitar kawasan.

Kebutuhan lahan pada masyarakat sekitar hutan sangat tinggi.

\section{Analisis SWOT}

Analisis SWOT Pengelolaan blok pemanfaatan di KHDTK HPP diawali dengan tahapan pendeskripsian potensi dari kondisi kawasan dan gambaran komprehensif mengenai permasalahan yang terjadi. Dari tahapan identifikasi tersebut di atas diharapkan dapat melahirkan gambaran kondisi dari KHDTK HPP Loa Haur. Selain itu dengan memperhatikan faktor-faktor lainnya dapat diidentifikasi faktor internal dan faktor eksternal. Berdasarkan hasil identifikasi faktor tersebut, kemudian dilakukan Analisis SWOT yang akan menghasilkan strategi operasional dan kebijakan serta program/kegiatan pokok sebagai dasar dan arahan dalam desain pengelolaan dan pengembangan blok pemanfaatan KHDTK HPP Loa Haur. 
Tabel 4. Analisis SWOT

\begin{tabular}{|c|c|c|}
\hline & Kekuatan (Strength) & Kelemahan (Weakness) \\
\hline $\begin{array}{c}\text { External } \\
\text { Factors }\end{array}$ & $\begin{array}{l}\text { KHDTK HPP Loa Haur telah } \\
\text { ditetapkan menjadi KHDTK } \\
\text { untuk Diklat. } \\
\text { Adanya regulasi pemerintah } \\
\text { terkait perhutanan sosial } \\
\text { Curah hujan tinggi } \\
\text { Tersedia tenaga penyuluh } \\
\text { Potensi jumlah masyarakat yang } \\
\text { cukup untuk membentuk } \\
\text { KTH }\end{array}$ & $\begin{array}{l}\text { Letak dan asksesibilitas kawasan } \\
\text { yang kurang mendukung } \\
\text { Potensi limpasan air sungai yang } \\
\text { tinggi } \\
\text { Sejarah alih fungsi penetapan } \\
\text { kawasan } \\
\text { Budaya/kebiasaan pembukaan } \\
\text { lahan dengan cara bakar }\end{array}$ \\
\hline Peluang (Opportunity) & Strategi SO & Strategi WO \\
\hline $\begin{array}{l}\text { Komitmen pemerintah yang kuat } \\
\text { dalam program perhutanan } \\
\text { sosial } \\
\text { Persentase luas kawasan } \\
\text { bervegetasi jarang dan semak } \\
\text { belukar relatif besar. } \\
\text { Terdapat rencana pengembangan } \\
\text { pemberdayaan masyarakat } \\
\text { pada rencana pengelolaan } \\
\text { kawasan. } \\
\text { Komitmen penentu kebijakan } \\
\text { nasional dan daerah bagi } \\
\text { pelestarian SDA dan } \\
\text { lingkungan. } \\
\text { Terdapat penyelenggaraan diklat } \\
\text { yang berbasis masyarakat. }\end{array}$ & $\begin{array}{l}\text { Pelaksanaan program dengan } \\
\text { pendekatan dan acuan sesuai } \\
\text { regulasi perhutanan sosial. } \\
\text { Perencanaan penataan dan } \\
\text { pemanfaatan luas kawasan } \\
\text { yang strategis bagi kegiatan } \\
\text { pemanfaatan. } \\
\text { Koordinasi antara pengelola dan } \\
\text { masyarakat dalam } \\
\text { perencanaan kawasan } \\
\text { pemanfaatan. } \\
\text { Kerjasama antara pihak } \\
\text { pengelola dengan masyarakat } \\
\text { dalam program kediklatan } \\
\text { masyarakat. }\end{array}$ & $\begin{array}{l}\text { Kerjasama dengan pihak } \\
\text { pengelola dan stakeholder lain } \\
\text { dalam pembangunan sarana } \\
\text { infrastruktur jalan. } \\
\text { Pengaturan pola dan sistem } \\
\text { pengelolaan lahan yang sesuai } \\
\text { Melaksanakan program } \\
\text { kemitraan yang komprehensif } \\
\text { secara legal formil. } \\
\text { Kerjasama dan pendampingan } \\
\text { dalam pengelolaan oleh } \\
\text { masyarakat }\end{array}$ \\
\hline Ancaman (Threath) & Strategi ST & Strategi WT \\
\hline $\begin{array}{l}\text { Isu kandungan batubara } \\
\text { Letak kawasan dekat dengan } \\
\text { pertambangan. } \\
\text { Meningkatnya jumlah penduduk } \\
\text { sekitar kawasan. } \\
\text { Masih rendahnya tingkat } \\
\text { pendidikan masyarakat sekitar } \\
\text { kawasan. } \\
\text { Kebutuhan lahan masyarakat yg } \\
\text { tinggi. }\end{array}$ & $\begin{array}{l}\text { Optimalisasi dalam } \\
\text { perlindungan dan } \\
\text { pengamanan kawasan. } \\
\text { Kerjasama dengan pihak swasta } \\
\text { sekitar kawasan dalam } \\
\text { program pem-bangunan } \\
\text { masyarakat. } \\
\text { Kerjasama dengan pemerintah } \\
\text { daerah dalam sosialisasi dan } \\
\text { penyuluhan masyarakat } \\
\text { Meningkatkan kapasitas } \\
\text { masyarakat dengan program } \\
\text { kediklatan dan sekolah } \\
\text { lapang. }\end{array}$ & $\begin{array}{l}\text { Pembangunan aksesibilitas jalan } \\
\text { Penyampaian informasi dan } \\
\text { sosialisasi antar masyarakat } \\
\text { dalam program kemitraan } \\
\text { Pembentukan Kelompok Tani } \\
\text { Hutan sebagai sarana diskusi } \\
\text { dan kerjasama antar individu } \\
\text { masyarakat. } \\
\text { Sosialisasi acuan peta sebagai } \\
\text { dasar perencanaan kegiatan }\end{array}$ \\
\hline
\end{tabular}




\section{Program Kolaborasi bersama Masyarakat \\ Kemitraan Kehutanan}

Berdasarkan analisis SWOT diketahui bahwa kondisi iklim, arahan blok, komitmen dan pengalaman serta budaya, potensi pengembangan kemitraan kehutanan di KHDTK adalah dengan mengembangkan tanaman keras. Analisis tentang kekuatan, kelemahan, peluang dan tantangan tersebut kemudian dielaborasi dalam proses resolusi dalam FGD.

\section{Proses resolusi Konflik}

Upaya penyelesaian konflik melalui kegiatan kemitraan kehutanan merupakan hal baru yang dilakukan oleh pengelola KHDTK HPP Loa Haur. Salah satu praktek terbaik (best practise) resolusi adalah seperti dilakukan oleh Perhutani (2007), yang dilakukan berdasarkan 10 prinsip PHBM. Langkah awal dalam pelaksanaan dimulai dengan mengubah pola pikir pengelola dari konsep yang birokratif / sentralistik / ditakuti menjadi fasilitatif / akomodatif / dicintai. Focus Grup Discussion (FGD) yang dilakukan memberi pengaruh kuat dalam perubahan pola pikir tersebut. FGD adalah juga menjadi media yang efektif untuk mendapat solusi dari isu dan aktifitas perambahan, klaim dan pembakaran lahan dalam pembukaan lahan garapan. Kesepahaman yang terbangun dalam FGD adalah sebagai berikut :

Memberi ijin pemanfaatan lahan untuk perladangan di dalam kawasan KHDTK

HPP Loa Haur, dengan kesediaan terhimpun dalam program kemitraan.
Pembukaan lahan untuk garapan dengan cara membakar hanya diperkenankan dengan syarat-syarat yang ketat dan didampingi petugas dari Balai. Dalam hal ini dibangun satu pembelajaran tentang upaya pencegahan kebakaran hutan dan lahan serta pengenalan praktek pembukaan lahan tanpa bakar (PLTB)

Hak pemanfaatan lahan tidak dalam bentuk hak milik karena statusnya sebagai hutan Negara. Dalam hal ini, dibangun satu kesepahaman bahwa kemitraan tidak bertujuan untuk mengubah status dan fungsi sebagai kawasan hutan negara.

Kesempatan kemitraan lain dibuka untuk pengembangan aktivitas perlindungan tanah dan air, rehabilitasi lahan, pengembangan wisata dan programprogram yang mendukung upaya pengelolaan kawasan secara aman, produktif dan ramah lingkungan.

Penyusunan Rencana

Kemitraan kehutanan dimaksudkan untuk memberikan arah pengelolaan sumberdaya hutan dengan memadukan aspek ekonomi, ekologi dan sosial secara proporsional dan profesional. Pertemuan dalam Focus Grup Discussion (FGD) diantaranya telah mengarah pada pencapaian tujuan kemitraan untuk peningkatan peran dan tanggung pengelola KHDTK HPP Loa Haur, Tahura Bukit Soeharto, masyarakat desa dan para pihak. Penyusunan rencana secara partisipatif pada prinsipnya adalah proses komunikasi untuk membangun pemahaman akan peran dan tanggung jawab masing-masing. 


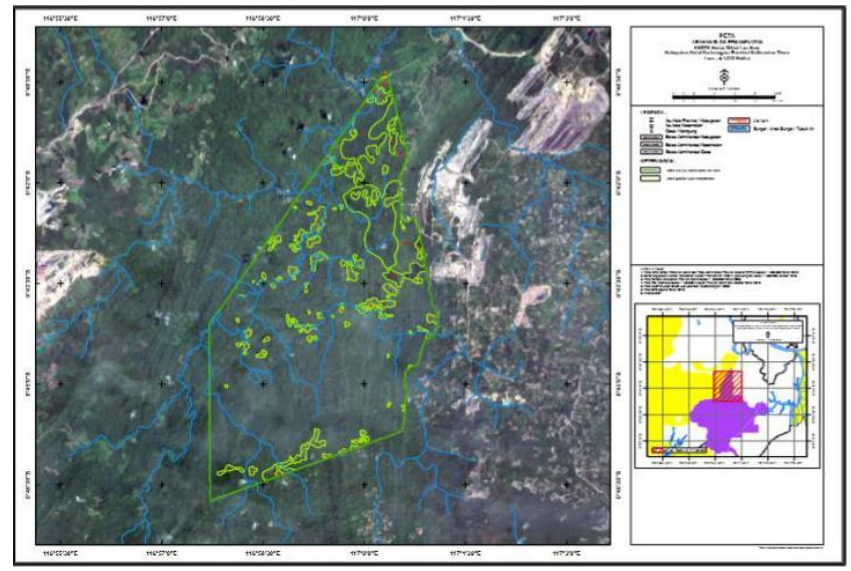

Gambar 7. Peta Arahan Blok Pemanfaatan Sumber : Pengolahan Data tahun 2017

\section{KESIMPULAN}

\begin{abstract}
Berdasarkan hasil pembahasan dapat ditarik beberapa kesimpulan sebagai berikut : Jumlah pemanfaatan lahan secara aktif oleh masyarakat yang teridentifkasi adalah sebanyak 20 lokasi lahan, dengan luas 43,58 ha dan rata-rata 2,18 ha.
\end{abstract}

Jumlah lahan yang teridentifkasi pernah dimanfaatkan dan lalu ditelantarkan dan tanpa identitas adalah lebih banyak. Berdasarkan hasil analisis penafsiran citra menunjukan luas areal terbuka di KHDTK HPP Loa Haur sebanyak 573,84 ha. Secara keseluruhan areal yang dapat diarahkan menjadi blok pemanfaatan adalah seluas 617,42 ha.

Berdasarkan analisa SWOT terhadap pengelolaan blok pemanfaatan di KHDTK HPP Loa Haur dapat disimpulkan bahwa pengelolaan kawasan dapat dilakukan dengan pola atau program kemitraan kehutanan sesuai dengan fungsi KHDTK HPP Loa Haur yang merupakan bagian dari Tahura Bukit Soeharto yang merupakan kawasan pelestarian alam.

\section{DAFTAR PUSTAKA}

Anonim, 2007. Peraturan Pemerintah Republik Indonesia Nomor 6 Tahun 2007 tentang Tata Hutan dan Penyusunan Rencana Pengelolaan Hutan serta Pemanfaatan Hutan. Website: http://www.cifor.org/ilea/Database/ dataijin/PP_6_2007.pdf . $D i$ download April 2018.

Anonim, 2007. Pengelolaan Hutan Bersama Masyarakat (PHBM), Kolaborasi antara Masyarakat Desa Hutan dengan Perum Perhutani. Perhutan bekerja sama dengan Uni Eropa, CIRAD, CIFOR dan Universitas Gajah Mada. Website: http://www.cifor.org/lpf/docs/java/ LPF_Flyer_PHBM.pdf. download April 2018.

Anonim, 2009. Surat Keputusan Menteri Kehutanan Republik Indonesia Nomor: SK.577/Menhut-II/2009 tanggal 29 September 2009 tentang Penetapan taman hutan raya bukit Soeharto yang terletak di kabupaten Kutai Kartanegara dan Kabupaten Penajam Paser Utara, Provinsi Kalimantan Timur seluas 67.766 ha. Website http://katalog.hukum.menlhk.go.id/ . Di download April 2018. 
Anonim, 2015. Peraturan Menteri Lingkungan Hidup dan Kehutanan Republik Indonesia No. P. 76/Menlhk-Setjen/2015 tentang Kriteria Zona Pengelolaan Taman Nasional dan Blok Pengelolaan Cagar Alam, Suaka Margasatwa, Taman Hutan Raya dan Taman Wisata Alam.

Anonim, 2015. Data Curah Hujan Taman Hutan Raya Bukit Soeharto. Kecamatan dalam angka. (Badan Pusat Statistik, Propivinsi Kalimantan Timur).

Boer, C. D; T. Sudarmadji; E. Iskandar; D. Aksa; Rustam dan Y. B. Sulistyoadi. 2007. Studi Pemetaan Beberapa Habitat Jenis Spesifik Hutan Dataran Rendah di Hutan Penelitian dan Pendidikan Bukit Soeharto, Laporan Penelitian PPHT Unmul, Samarinda.

Hendar, 2014. Korupsi Tambang di Bukit Suharto, Potensi Kerugian Negara 18,2 Triliun. Mongabay Situs Berita Lingkungan. Website : www.mongabay.co.id/2014/05/29. Download : 22 April 2018.

Moeliono,M. and Purwanto, E. 2008. A Park in Crisis: Local Governance and National Policy. Paper presented at "Governing shared resources: connecting local experience to global challenges" $12^{\text {th }}$ Biennial Conference of the International Association for the Study of The Commons, Cheltenham, England, July 14-18 2008.

Nurdiani, N. 2014. Teknik Sampling Snowball dalam Penelitian Lapangan. ComTech Vol. 5 No. 2 Desember 2014: 1110-1118
Prahasta, Eddy. 2002. Sistem Informasi Geografis Konsep-konsep Dasar. Bandung: Informatika

Purwadhi, F., dan S. Hardiyanti. 1999. Sistem Informasi Geografis. Kedeputian Bidang Penginderaan Jauh, Lembaga Penerbangan dan Antariksa Nasional. Jakarta.

Rangkuti, Freddy, (2000), Analisis SWOT : Teknik Membedah Kasus Bisnis, PT. Gramedia Pustaka Utama, Jakarta.

Sudiana, D dan Diasmara, E. 2008. Analisis Indeks Vegetasi menggunakan Data Satelit NOAA/AVHRR dan TERRA/AQUA-MODIS. Seminar on Intelligent Technology and Its Applications 2008. ISBN 978-9798897-24-5

Sumaryono, Sutedjo, S. Hardwinarto, A. Suhardiman, 2009. Studi Degradasi Hutan Terhadap Penyerapan Karbon dan Perubahan Iklim Mikro Tegakan Hutan Alam Di Hutan Pendidikan dan Penelitian Unmul Bukit Soeharto. Penelitian Strategis Nasional, 2009.

Suryadi, Aipassa, Ruchaemi \& Matius, 2017. Studi Tata Guna Kawasan Taman Hutan Raya Bukit Soeharto. Jurnal Penelitian Ekosistem Dipterokarpa Vol. 3 No.1, Juli 2017: 43-48. DOI: http://dx.doi.org/ 10.20886/iped.2017.3.1.43-48

Vaiphasa, C. S. Ongsomwang; T. Vaiphasa and A.K. Skidmore. 2005. Tropical Mangrove Species Discrimination Using Hyperspectral Data: A laboratory Study. Estuarine, Coastal and Shelf Science 65: 371-379 